\title{
Export competitiveness analysis of Pakistan garments industry based on GEM Model
}

\section{REZUMAT - ABSTRACT}

\section{Analiza competitivității exportului din industria de îmbrăcăminte din Pakistan pe baza modelului GEM}

Obiectivul principal al acestui studiu de cercetare este de a investiga competitivitatea exportului din industria de îmbrăcăminte din Pakistan pe piețele globale prin aplicarea modelului GEM. Modelul GEM este aplicat pe scară largă în multe industrii pentru a analiza competitivitatea exportului unui anumit cluster. Metoda sondajului se aplică colecției de date primare printr-un chestionar structurat. Competitivitatea exportului din industria de îmbrăcăminte din Pakistan bazată pe modelul GEM este analizată utilizând tehnica procesului de ierarhie analitică (AHP). După o analiză detaliată, scorul GEM total calculat este 382 pentru industria de îmbrăcăminte din Pakistan. Scorul GEM 382 înseamnă că industria de îmbrăcăminte din Pakistan depășește nivelul mediu național și posedă avantaje competitive la nivel național. Obiectivul viitor al cercetării este că pot fi studiate asociațiile dintre unul sau mai mulți alți factori pentru a verifica nivelul de competitivitate al industriei de îmbrăcăminte din Pakistan. Această activitate de cercetare are implicații practice foarte importante pentru toate părțile interesate de a evalua nivelul de competitivitate a exportului din industria de îmbrăcăminte. Prin aplicarea modelului GEM, organizația poate evalua punctele forte și punctele slabe ale acesteia, astfel încât să poată face față concurenței internaționale și lua decizii pentru afacerile lor.

Cuvinte-cheie: industria de îmbrăcăminte din Pakistan, exporturi, competitivitate, model GEM, piețe globale

\section{Export competitiveness analysis of Pakistani garments industry based on GEM Model}

The main purpose of this research study is to investigate export competitiveness of Pakistani garment industry in the global markets by applying the GEM Model. GEM model is vastly applied in many industries to analyse the export competitiveness of the particular cluster. Survey technique applies to primary data collection through a structured questionnaire. Pakistani garments industry export competitiveness based on GEM Model is analysed by using the analytic hierarchy process (AHP) technique. After thorough analysis, overall calculated GEM score is 382 for Pakistani garment industry. GEM score 382 means that Pakistani garment industry is above the national average level and possess country wide competitive advantages. The future research scope is that there can be studied the associations between one or many other factors to check the competitiveness level of Pakistani garment industry. This research work has very important practical implications for all stakeholders to evaluate the export competitiveness level of the garment industry. By applying the GEM model, the organization can evaluate its strengths and weaknesses, so that organizations can cope with the international competition accordingly which is supportive to make decisions for their businesses.

Keywords: Pakistani garment industry, exports, competitiveness, GEM Model, global markets

\section{INTRODUCTION}

The textile industry is playing a key role in the growth of Pakistan's economy. Pakistan is the $8^{\text {th }}$ major significant textiles merchandise exporter in Asia. Pakistani textiles pay almost $9.5 \%$ of Gross Domestic Product (GDP) of Pakistan. This industry employed approximately 15 million people of the country. Pakistan has huge cotton resources which are utilized by the textile industry for value addition in different textile products like clothing, garments, and apparel that are helpful to grow economically. At present, there are 1,221 cotton ginning companies, 442 yarn spinning firms, 124 big yarn spinning firms, 425 medium and small size enterprises are operating which are producing different textile products [1]. The textile industry has inherited with cheap labor and raw material, but still, the industry is lacking in some areas. There is strong need to speak and cure them and need to improve the sector performance [11]. The textile process is lengthy from the production of cotton to final ready-made garment production but despite having all the many other advantages, even Pakistan's international share in the world market is less than $1 \%$ which needs work out and to improve the international trade. The Pakistani ready-made garment industry has the capability to produce and offer large volumes in different international markets. The Pakistani textile industry is well competent to produce different sorts of ready-made garments for men, women, girls, and boys, etc. The garments export of Pakistan has been improved from 21.434 million dozen in various sorts of ready-made garment exports of the amount with US\$ 1426.826 million July to March 2013-14. These figures have been improved to 22.843 million dozens of the amount with $\$ 1548.282$ million July to March 2014-15; consequently, this 
was presenting 8.51 percent upsurge and also increased the value of ready-made garment industry [6]. Pakistan has been pursuing an open gate economic policy over a couple of past decades. Pakistan was the first in South Asia region that adopted a generous economic policy by liberalizing and shrinking the government control, encouraging the private sector, and privatizing country's assets and liabilities [9]. Growing anxiety about competitiveness can be acknowledged the response to economic issues which are confronting the nation. Across the globe, economies can be characterized according to their industrialisation level and the competitiveness level that they have achieved. Developed countries are considered to be more competitive than developing countries. With the passage of time developing countries have applied numerous approaches to get better industrialization and competitiveness level [21]. Across the world, governments are frequently appealing to define the competitiveness a very important objective in their nationwide economic planning policy [15]. Competitiveness is associated with economic consequences in diverse means like precise objectives or advancement i.e. job formation or foreign direct investment. All the advancement of opinions on competitiveness has proposed the main three thoughts like product cost, international market share, and productivity outcomes [5].

Pakistan has a competitive advantage of being a $4^{\text {th }}$ largest cotton producer in the world and also has the capability to increase the output of cotton crop through utilizing different production techniques. There are many factors for the decline in cotton crop production like the effect of insect pests, cultivation area, the situation of the disease, and the role of the government. In the year 2016, cotton was sowed 20 percent less area in Punjab due to consistent lower price trend, lessening rate of return compared to other crops production and situation of the weather forecast [17]. Global textiles products businesses are playing vital Pakistan's economic growth.

Competitiveness has been widely studied all over the world but in textile sector of Pakistan comprehensive research study still lacking concerning competing at an industry cluster level [12]. The Export trend of Pakistan Textiles showed that despite rich resources in cotton still, Pakistan is in the lowest position with having less than $1 \%$ market share in global markets. Even Bangladesh, UAE, Sweden and many other countries have good export volume in international markets. At present, Pakistan is facing tough competition from major giants in the region. In current situation, some Asian countries like India, Bangladesh, China, South Korea, Malaysia, and Thailand are achieving a good export share in the global markets [9]. Generally, textiles are a labour intensive industry. It is suggested that huge volume textiles producing countries, for example, China, India, Pakistan and Bangladesh have attached worldwide economies since the year 1980s [14].
Pakistan is the main supplier of textile products including grey clothing, finished clothing, apparel, ready-made garments and other textile products in the international markets. In one way, Pakistan's internal domestic markets are also growing for textiles products and garments demand and ultimately this would be helpful for growing the income source of Pakistan. A readymade garment export data of different countries for the year of 2012-13 and the year of $2013-14$ is in table 1.

Table 1

\begin{tabular}{|l|c|c|}
\hline \multirow{2}{*}{\multicolumn{1}{|c|}{ Country }} & \multicolumn{2}{c|}{ Value (USD \$Millions) } \\
\cline { 2 - 3 } & $\mathbf{2 0 1 3 - 2 0 1 4}$ & $\mathbf{2 0 1 2 - 2 0 1 3}$ \\
\hline United State of America & 498,203 & 515,595 \\
\hline United Kingdom & 261,329 & 234,368 \\
\hline Spain & 227,517 & 201,238 \\
\hline Germany & 190,963 & 240,486 \\
\hline Belgium & 129,099 & 114,092 \\
\hline Netherlands & 118,414 & 67,205 \\
\hline France & 85,138 & 17,651 \\
\hline Italy & 75,890 & 62,485 \\
\hline UAE & 46,349 & 38,999 \\
\hline Sweden & 38,980 & 32,669 \\
\hline Canada & 34,198 & 35,761 \\
\hline Bangladesh & 24,492 & 21,515 \\
\hline Poland & 22,802 & 16,326 \\
\hline Norway & 17,623 & 12,036 \\
\hline Japan & 10,542 & 5,969 \\
\hline China & 10,315 & 7,432 \\
\hline Mexico & 8,051 & 5,349 \\
\hline Singapore & 7,829 & 3,462 \\
\hline Hong Kong & 6,106 & 4,367 \\
\hline Malaysia & 5,462 & 4,209 \\
\hline Finland & 4,655 & 3,781 \\
\hline Portugal & 4,592 & 2,333 \\
\hline Greece & 3,854 & 2,879 \\
\hline Pakistan & 1,909 & 1,800 \\
\hline Total & $1,834,312$ & $1,652,007$ \\
\hline
\end{tabular}

Source: Trade Development Authority of Pakistan (Adapted from Readymade garment industry, Dr. Noor (2015), Pakistan Textile Journal)

This research study has worked on the competitive advantages and improved competitiveness of garments industry through GEM model introduced by Tim Padmore and Hervey Gibson. The Porter diamond model guides and improves the thoughtful for organization's international export competitiveness level in diverse product ranges [20]. This is first competitiveness theory that persuasively connected with industries, firms, and nations [18].

GEM formula is the main application to calculate the final score to know that where the garment industry stands up in present situations. If all six factor score 
is on point 5 , it means every factor of the cluster touched at average level; in this case, GEM score would be 250 points which specifies industry cluster competitiveness grasped at average in its country. Likewise, if all six factors score is on point 7 , it means that the GEM score would be around 490 points that specifies the competitiveness level of the industrial cluster is very much strong in the nation. If all six factors score is close to 10 points, it means GEM score would be near to 1000 that specifies industrial cluster's competitiveness level is categorized like a first or second class in the whole world [3].

\section{RESEARCH PROBLEM STATEMENT}

This research study works on ready-made garment industry of Pakistan, which has potential to enhance the garment exports in global markets. Pakistan's competitiveness position was very depressing as compared to new emerging economies, so, Pakistani garment industry experts had poor performance in the global markets [31]. After 2007 no study has been reported on the competitiveness of Pakistani ready-made garments. So the purpose of this study to assess the current competitiveness of Pakistani garment industry through GEM Model.

\section{GARMENTS INDUSTRY CLUSTER COMPETITIVENESS BASED ON GEM MODEL AND EVALUATION PROCESS}

The GEM model consists of six classifications which influence the firm's competitiveness as well as the industry. It comprises of "resources", "infrastructure", "supplier \& related industries", "enterprise structure, strategy and rivalry", "local market", "external market" [27].

The six classifications are collected in three main pairs.

Groundings is comprised of resources, and infrastructure which named as a factor pair I.

Enterprises comprise of supplier and related industries and enterprise structure, strategy and rivalry, which named as factor pair II.

Markets comprises of local market \& external market, which named as factor pair III.

\section{Groundings factor pair I}

Groundings contain resources, and infrastructures, that is contained to deliver main raw material input elements supply to business firms to their supply chain process. The details are as under:

\section{Resources}

Resources originated usual, instinctive or established in the nation. Normal resources are comprised of the land, forest, labour supply, patent, expertise, stock exchanges, capital markets and planned environmental position of the state.

\section{Infrastructure}

Infrastructure includes corporal structures, the official arrangements which are helpful to accelerate easy methods to resource mobilizations, support and to run efficiently. Corporal infrastructure comprises of mostly roads, air ports, sea ports and infrastructure of communication. The incorporeal infrastructure comprises of like research laboratories, training institutes, business associations, business markets, regulatory systems and tax systems, financial markets, research $\&$ development institutions, and perfection of associated laws $\&$ rules.

\section{Enterprises factor pair II}

Enterprises, comprised of suppliers and related industries, the firm's structure, strategy and rivalry which means that physical and nonphysical elements of organizations internally and externally which decide cluster's production efficiency.

\section{Supplier and related industries}

Supplier \& related industries comprised of products \& facilities usages of other organizations in the country. Triumph dynamics contained buyers and supplier quality relationships, the products and service's cost and product quality performance that supports organizations, businesses and to support and develop the associated businesses.

\section{Firm structure, strategy, and rivalry}

Firm structure, strategy, and rivalry mean firm's hierarchal levels, firms' strategies in various areas, arrangement manners of products \& services, manufacturing amongst firms, the management mode of enterprises and firms proprietary right structure and the scales of enterprises and number in the cluster of the government. The firm's structures influence the competition tactics and strategy path in the whole firm's cluster.

The firm's size and effective management of production can make an effective value-chain in cluster nimble. Therefore complete management working style and the proprietary right structure of the organizations in a given cluster have a significant impact whichever firms have flourished by cost benefits, distinction etc. These good benefits are too supportive to describe the organization's planning and strategies to function efficiently in domestic and global markets.

\section{Markets factor pair III}

Market refers that the products and services demand situations in domestic and global markets of organizations in the given cluster.

\section{Local markets}

Local markets also refer the national marketplaces. Local could be defined as region marketplaces, the district or nationwide marketplaces. Local market differs in provinces and cities in nationwide. The dissimilarity among internal and worldwide markets is the worldwide marketplaces are widespread whereas local marketplaces are narrow to particular a state. Market size, market prospects, market share and market growth is very important in the local market while considering the degree of national sourcing buyers, product quality standards and uniqueness of national demand with the native cluster of an industry. 


\section{External markets}

External markets vary than local markets. The pressures on the significance of discerning internal markets, the clusters which are generally exported oriented [20]. For further clusters, the external market approach is very thoughtful from the outer buyers [24]. Different regions confront pretty much regular arrangement of outside business sectors excluding native markets. With different regions distinguishes, there is also a different approach to target the external markets. It comprised some issues like markets intimacy, market size, market growth rate level, entry barriers to other markets, the worldwide market share of the region for a particular cluster and other trade barriers for other businesses and firms. GEM Model is shown in figure 1 .

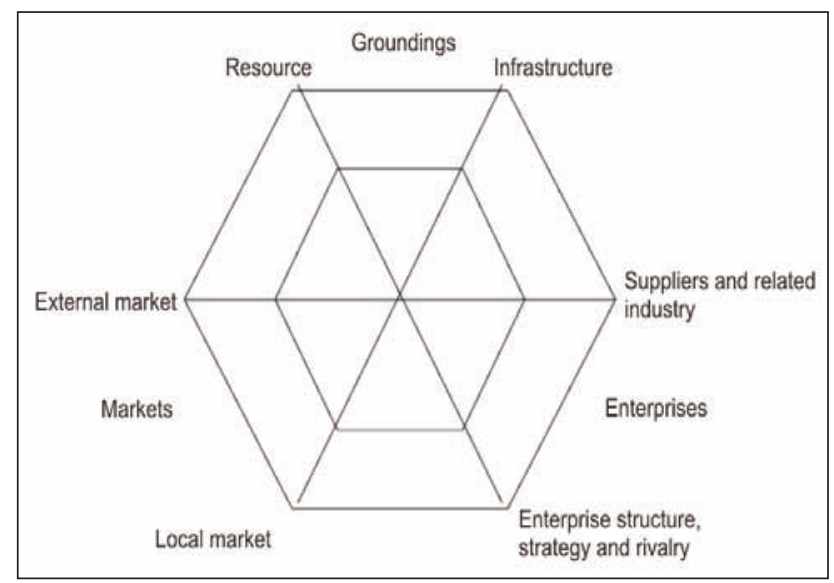

Fig. 1. The GEM Model [16]

\section{RESEARCH METHODOLOGY}

In order to conclude this research paper, a quantitative research approach has been applied. Primary data collected through a structured questionnaire from renowned Pakistan's garments industry marketing professionals with having a master degree along with 5 years' experience or more. Primary data also collected from research scholars and industry experts for better assessment of the Pakistani garments industry export competitiveness level. This research study examined the ready-made garment industry by using the analytic hierarchy process (AHP) technique and analysing the export competitiveness by applying the GEM model to Pakistan's garment industry. GEM model is developed by two Canadian scholars Tim Padmore and Hervey Gibson with the improvement of "Diamond Model" by Michael Porter's, the competitiveness evaluation of industry cluster Groundings, Enterprises, and Markets. GEM model comprises of main three factors of six determinants [30]. The GEM model had been already applied in the different countries like in Canada and United Kingdom primarily in consulting viewpoint [16]. GEM model supports the garment industry to evaluate the competitiveness through applying the AHP technique and analysis results guides to make good decisions for the garment industry competitiveness level in domestic and global markets.

This research work applied the random and particularly purpose sampling technique for primary data collection from real respondents of Pakistan's renowned ready-made garments production units. For primary data collection, this research work applied the survey technique. The first part of a structured questionnaire developed on a 10 Likert scale scoring basis to collect data from garments industry marketing experienced professionals with having five years' experience and master degree qualification, preferably M.B.A Marketing and second part of a structured questionnaire developed on a 7 Likert scale to know the importance of sub-factors organized to fill from industry experts and researchers around the country. Respondents are given the scores and weighted to structured questionnaire according to the real situation of the problems in the industry. Scoring means the procedure which is involved in subjective assessment from real respondents by way of supposition means respondents have full knowledge grasped and understanding on the subject of competitiveness with the purpose of rationality.

In the first part of questionnaire 1, about 150 experienced professionals approached of 25 different garment units which are operating in Pakistan with different production scales from small to large scale levels for ready-made garment production. After through putting efforts finally collected 115 filled structured questionnaires from valid and real respondents. The first part of questionnaire 1, average response rate was almost $76.67 \%$ with 59 respondents of large garment production firms having more than 2,000 Million Pak Rupees annual turnover, sales volume, 39 respondents of medium garment production firms having annual turnover, sales volume among 500 to 1,000 Million Pak Rupees, 17 respondents of small garment production firms annual turnover sales volume lesser than 500 Million Pak Rupees.

In the second part of questionnaire 2, about 25 industry experts, researchers, and consultant approached overall in Pakistan for primary data collection. After putting hard efforts, finally collected 21 filled structured questionnaires from the valid and real respondents with an average response rate almost $84 \%$. Wang et al., (2005) circulated about 173 Structured Questionnaires 1 and received 107 filled questionnaires with valid response rate about $61.8 \%$ and Structured Questionnaire 2 total circulated 25 to different researchers, consultants and experts, he collected 19 filled questionnaires with valid response rate about $76 \%$ for data analysis.

\section{ANALYTIC HIERARCHY PROCESS (AHP)}

Analytic Hierarchy Process rationally comprises of three normal steps [29]:

(i) The hierarchy structure.

(ii) Comparative assessments, or defining \& accomplishment of collecting data collection to develop 
the valuation data in the form of pairs in hierarchical structure form.

(iii) Creating priorities or building priorities with complete ranking.

AHP scoring matrix applied as the main tool to examine the primary data collected from the garment industry and research scholars and industry experts of Pakistan. Saaty [23], first suggested about the Analytic Hierarchy Process technique, meanwhile its advancement in AHP, this is the best tool for the researchers and decision makers and AHP is one of the utmost mostly used tool for decision making purpose and based on the multiple measures for decision makers [23, 26]. Analytic Hierarchy Process refers to the theory of measurements comprising pair's assessments and it too depends upon the expert's thoughts to choice priority gauges [7].

Analytic Hierarchy Process provisions various characteristics of ranking in hierarchal form, thus AHP permit governments and business consultants to focus on the utmost significant matters [4]. All assessments are prepared by applying complete judgments a scale that explains how a single factor leads to another one as compare to its main factors [23]. AHP is not just backings the experts to settle on the great decisions, be that as it may, this likewise coordinated a reasonable clarification settled for the decision makers [2].

\section{RESEARCH RESULTS}

According to the problem statement, this quantitative research process continued with the following three stages.

The first stage involved the subjective scores of subfactors that are influencing specific cluster's competitiveness level. As per GEM model, all factors are scored on a Likert scale within the scoring range from 1 to 10 which are itemized as per following:

$10=$ Extremely Excellent refers being top first or second in competitiveness at international level.

9 = Excellent refers being in among top five with good competitiveness at international level.

$\mathbf{8}=$ Very good refers that having exclusive competitive advantages across the country.

$7=$ Good refers having competitive advantages in the country.

$6=$ Not bad refers no competitive advantages, but excelling in the nation at anaverage level.

$\mathbf{5}=$ Mean level refers having an average strength at the national level.

4 = Limited level refers having slightly below average strength at the national level.

$\mathbf{3}=$ Very limited level refers having certain gaps in comparison to the national average strength and these gaps influenced the competitiveness of garment industry.

$\mathbf{2}=$ Poor refers having significant gaps, those gaps influence the competitiveness of garment industry.

1 = Extremely poor refers vast gap in comparison to the national average strength and this gap hindered rigorously garments industry developments.
By using the AHP technique and through a quantification process, a thorough analysis will perform based on GEM Model. In the meantime, it is necessary to decide all sub-factors weight's importance to their conforming factors. Second part every factor is categorized in the series from 1 to 7 that is displaying sub-factors importance to its key factors.

The second stage quantification process is started to compute the results and convert to the factor pairs. Pertinent formulas are quantified here as per following:

$\mathrm{D}_{\mathrm{ij}}=\sum(\text { Final Score })_{\mathrm{ik}}=\sum(\text { Score })_{\mathrm{ik}} \times(\text { Weight })_{\mathrm{ik}}$

Here $(\boldsymbol{i}=1 \sim 3, \boldsymbol{j}=1 \sim 2, \boldsymbol{k}=1 \sim \boldsymbol{n}$ and $\boldsymbol{n}$ is measured like number of the sub-sets)

$(\text { PAIR SCORE })_{\mathrm{i}}=\left(\mathrm{D}_{2 \mathrm{i}-1}+\mathrm{D}_{2 \mathrm{i}}\right) / 2$

$(\text { PAIR SCORE })_{\mathrm{i}}=$ Refers that every factor pair score $\left(D_{2 i-1}+D_{2 \mathrm{i}}\right)=$ Which presenting the factor's scores Here factor pair is displaying the demonstration as $\left(D_{2 i-1}+D_{2 i}\right)$ that is comprised of two main factors and these factors can be altered by every other. As per GEM model concept, two factors could be replaced by everyone. Such as, complete infrastructures may cover the scarcity of resources in particular industry clusters and vice versa.

Third stage required to compute the (LCS) Linear Cluster Scores of totally factors pairs to calculate final score of competitiveness for Pakistan's ready-made garment industry. Following formulas would be used to know the final results:

LINEAR CLUSTER SCORE $=\|_{i=1,3}(\text { PAIRSCORE })_{i}$ GEM = $2.5\left(I I_{i=1,3}\left(D_{2 i-1}+D_{2 i}\right)^{2 / 3}\right.$

Linear Cluster Score (LCS) transmutes into numerous factors such as included all the three factors pairs. This refers that those factors influenced each one effectively. For instance, if the score of one, or two factors pair is low, it means that it might move to the lower most level of competitiveness in given cluster. If the score of one or two factors pair is high, it means that it might move to most-highest level of competitiveness in a cluster. In actual sense, if a factor pair likes infrastructure and resources have the lowest score whereas other factors pair's supplier \& associated industry, firm structures, strategy \& rivalry, local markets, and external markets have maximum level scores of whole factors pairs. In this case, garment business cluster would be unable to find the competitive edge in all markets (due to lowest score in resources and infrastructure) as compare to competitors in that particular industry. There would be balanced competitive edges in all these factor pairs to optimum utilization of the garments industry potential (table 2).

\section{Collected primary data's statistical calculations}

According to data received as per above in table 2, the scores of all these six determinants $\left(D_{i j}\right)$ received from the garments industry as per following formulas:

$$
\mathrm{D}_{\mathrm{ij}}=\sum(\text { Score })_{\mathrm{ik}} \times(\text { Weight })_{\mathrm{ik}}
$$




\begin{tabular}{|c|c|c|c|c|c|c|}
\hline Factor & No. & Sub factor & $\begin{array}{l}\text { Avg. } \\
\text { score } \\
(1-10)\end{array}$ & Weights & $\begin{array}{c}\text { Importance } \\
\text { score } \\
(1-7)\end{array}$ & $\begin{array}{c}\text { (Average } \\
\text { score) * } \\
\text { (weight) = } \\
\text { final score }\end{array}$ \\
\hline \multirow{3}{*}{ Resources (D1) } & D1-1 & Labour force resources availability & 7.1043 & 0.3447 & 6.2381 & 2.4487 \\
\hline & D1-2 & Talent Resources Availability & 6.0261 & 0.3286 & 5.9524 & 1.9804 \\
\hline & D1-3 & Geographic Location & 7.2435 & 0.3267 & 5.9048 & 2.3664 \\
\hline \multirow{9}{*}{$\begin{array}{l}\text { Infrastructure } \\
\text { (D2) }\end{array}$} & D2-1 & Transportation infrastructure & 7.1043 & 0.1204 & 6.2381 & 0.8555 \\
\hline & $\mathrm{D} 2-2$ & Communication infrastructure & 7.3391 & 0.1242 & 6.4286 & 0.9117 \\
\hline & D2-3 & Markets infrastructure & 6.3304 & 0.0994 & 5.1429 & 0.6290 \\
\hline & D2-4 & Trade Association & 5.4000 & 0.0915 & 4.7619 & 0.4939 \\
\hline & D2-5 & Business Environment & 6.3913 & 0.1119 & 5.8095 & 0.7153 \\
\hline & D2-6 & Perfection of associated laws/rules & 7.2000 & 0.1204 & 6.2381 & 0.8671 \\
\hline & D2-7 & Local Financial Market & 6.1826 & 0.1045 & 5.4286 & 0.6464 \\
\hline & D2-8 & R\&D Institution & 5.2783 & 0.1177 & 6.0952 & 0.6214 \\
\hline & D2-9 & Vocational Training & 4.4870 & 0.1099 & 5.7143 & 0.4932 \\
\hline \multirow{3}{*}{$\begin{array}{c}\text { Supplier \& } \\
\text { Related } \\
\text { Industries (D3) }\end{array}$} & D3-1 & Raw material availability & 7.6522 & 0.3555 & 6.5238 & 2.7203 \\
\hline & D3-2 & Services of suppliers & 6.3913 & 0.3367 & 6.1905 & 2.1522 \\
\hline & D3-3 & Development of related industries & 5.5304 & 0.3078 & 5.6667 & 1.7021 \\
\hline \multirow{6}{*}{$\begin{array}{l}\text { Firm Structure, } \\
\text { Strategy \& Rivalry } \\
\text { (D4) }\end{array}$} & D4-1 & Managerial skills & 5.8435 & 0.1629 & 5.9048 & 0.9521 \\
\hline & D4-2 & The clarity of property right & 4.6435 & 0.1400 & 5.0952 & 0.6499 \\
\hline & D4-3 & The level of value added & 6.1652 & 0.1737 & 6.2857 & 1.0710 \\
\hline & D4-4 & The worth of brand name & 7.1652 & 0.1610 & 5.8571 & 1.1538 \\
\hline & D4-5 & Production Equipment & 7.0174 & 0.1751 & 6.3333 & 1.2287 \\
\hline & D4-6 & Product Quality & 8.0957 & 0.1873 & 6.7619 & 1.5160 \\
\hline \multirow{3}{*}{$\begin{array}{l}\text { Local Markets } \\
\text { (D5) }\end{array}$} & D5-1 & Local market distinctiveness & 4.1826 & 0.3388 & 5.2857 & 1.4172 \\
\hline & D5-2 & Local market share & 4.2696 & 0.3151 & 4.9524 & 1.3452 \\
\hline & D5-3 & Local market potential & 5.3217 & 0.3461 & 5.4286 & 1.8418 \\
\hline \multirow{4}{*}{$\begin{array}{l}\text { External Markets } \\
\text { (D6) }\end{array}$} & D6-1 & Features of foreign end user & 6.3739 & 0.2444 & 5.6667 & 1.5575 \\
\hline & D6-2 & Export \& trade barriers & 5.6435 & 0.2526 & 5.8571 & 1.4257 \\
\hline & D6-3 & International market share & 6.1826 & 0.2422 & 5.6190 & 1.4976 \\
\hline & D6-4 & Foreign market relationship & 7.3826 & 0.2608 & 6.0476 & 1.9254 \\
\hline
\end{tabular}

Source: Developed by the author

Here $(\boldsymbol{i}=1 \sim 3, \boldsymbol{j}=1 \sim 2, \boldsymbol{k}=1 \sim \boldsymbol{n}$ and $\boldsymbol{n}$ is measured as number of the sub-sets)

Resources $\left(D_{1}\right)=6.7955$

Infrastructure $\left(D_{2}\right)=6.2334$

Supplier \& Related Industries $\left(D_{3}\right)=6.5746$

Firm Structure, Strategy \& Rivalry $\left(D_{4}\right)=6.5715$

Local Markets $\left(D_{5}\right)=4.6043$

External Markets $\left(D_{6}\right)=6.4061$

Average Determinants Score $\left(D_{i j}\right)=6.1976$

After calculations of all other determinants stated as above, then factor pair score can be calculated by using following formula:

$$
(\text { PAIR SCORE })_{i}=\left(D_{2 i-1}+D_{2 i}\right) / 2
$$

$(\text { PAIR SCORE })_{i}=$ Refers that each factor pair score $\left(D_{2 i-1}+D_{2 i}\right)=$ Which showing the scores of factors $(\text { PAIR SCORE })_{1}=(6.7955+6.2334) / 2=6.5145$ $(\text { PAIR SCORE })_{2}=(6.5746+6.5715) / 2=6.5731$ $(\text { PAIR SCORE })_{3}=(4.6043+6.4061) / 2=5.5052$
Finally, Linear Cluster Score (LCS) is calculated to know the competitiveness level of the readymade garments industry by applying formulas:

LINEAR CLUSTER SCORE $=\|_{i=1,3}(\text { PAIRSCORE })_{i}$ LINEAR CLUSTER SCORE= 6.1976 (Average Score)

GEM = $2.5\left(I_{i=1,3}\left(D_{2 i-1}+D_{2 i}\right)^{2 / 3}\right.$

After performing all other calculations, then here calculates the GEM Score of ready-made garment industry of Pakistan, which is $\mathbf{3 8 2}$ by applying the standard formula:

$$
\text { GEM }=2.5 \times\{\Pi \mathrm{i}=1,2,3(\mathrm{D} 2 \mathrm{i}-1+\mathrm{D} 2 \mathrm{i})\} 2 / 3
$$

GEM $=2.5 \times\{(6.7955+6.2334) \times(6.5746+6.5715) \times$

$$
\times(4.6043+6.4061)\} 2 / 3
$$

$\mathrm{GEM}=2.5 \times\{(13.0289) \times(13.1461) \times(11.0104)\} 2 / 3$

$\mathrm{GEM}=2.5 \times\{(1885.8527)\} 2 / 3$

GEM $=2.5 \times 152.6412 \quad$ GEM SCORE $=\mathbf{3 8 2}$ 


\section{The results and discussion}

The competitiveness of the firm level mostly dependent upon the competence of the firm to allocate its resources to yield or supply the superior products to those offered by the competitors and fulfilling all the posed challenges for survival in the global markets [8]. The whole GEM Score is 382 only for the Pakistani read-ymade garments industry which is based on primary data collection based on garments units from small scale to large scale level. This research study can be generalized in the textile industry of Pakistan because garments manufacturing units are enjoying the same facilities and benefits and also facing the same problems in the whole country as given by the Government of Pakistan. Based on the GEM Score 382, if the score is between 250 and 640, it means Pakistan readymade garments industry is above the national average level and owns competitive advantages nationwide. If all the six factors score is on point 5 , it means every factor of the cluster touched at average level; in this case, GEM score would be 250 points which specifies industry cluster competitiveness grasped at average in its country. Likewise, if all six factors score is on point 7 , it means that the GEM score would be around 490 points that specifies competitiveness level of the industrial cluster is very much strong in the nation. If all six factors score is close to 10 points, it means GEM score would be near to 1000 that specifies industrial cluster's competitiveness level is categorized like a first or second class in the whole world [3]. There is a convinced correlation among all factors and the industry cluster situation can be fully shown through all these GEM model six factors [28]. The GEM determinants real factors scores can be shown in following GEM Model (figure 2):

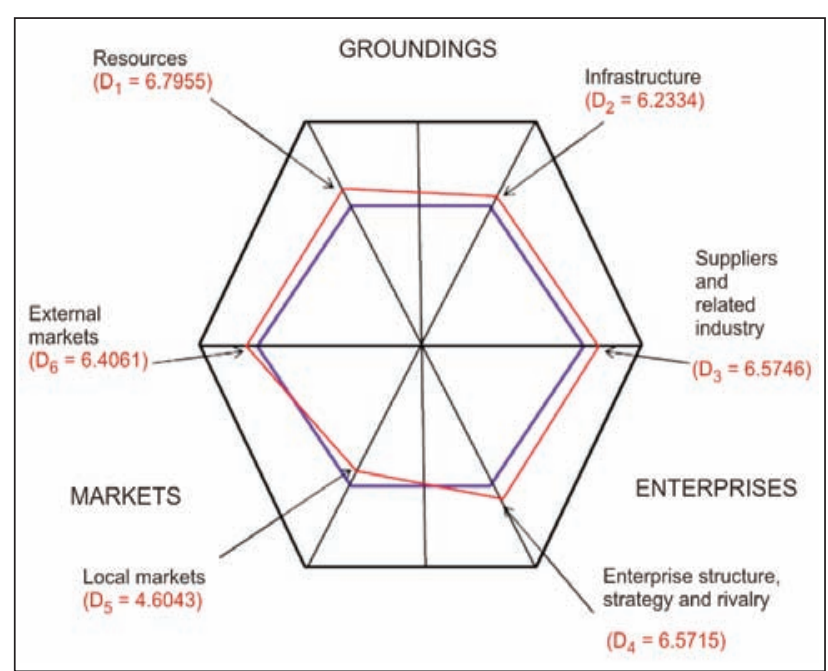

Fig. 2. The average score of all determinants in actual GEM Model

As per above quoted GEM Model in real Pakistani garment industry scenario, outward lines (red) are shown the Pakistani garment industry real average scores, whereas inward lines (blue) are shown standard 5 scores, in which outward lines are more than
5 scores while inward lines showed less than 5 scores.

According to primary data collected from the ready-made garments industry, Resources and Infrastructure average score is 6.7955 and 6.2334 respectively which is not bad and touching towards good. It means the ready-made garment industry is shifting to the good side with having lots of competitive advantages across the nation. The Pakistani ready-made garment industry has good labour pool availability and there is also good and abundant talent availability to manage the business enterprises effectively and on a long term basis. Pakistan has ample resources of best characteristics cotton which is helpful to produce good quality garments and competitive. Pakistan is located on good geographic area on world map, it means Pakistan has a good and easy approach to worldwide markets and Pakistan has also the good advantages of deep sea ports, so this research study is very much helpful to guide the industrialists in a better way to increase the garment exports in the global markets. But on the other hand, the garment industry should be focused to develop the employee training to arrange the skilled employees for the given industry. Pakistan's garments industry has good roads infrastructure and transportation system; there is also a good communication infrastructure which facilitates to increase the garment exports. $\mathrm{N}$ and innovated technology facilitate contacting the foreign customers rapidly and with low cost like Skype, mobile phone, vibor and whatsapp etc. In Pakistan, many textile associations are working and backing of the Pakistani ready-made garment industry.

Suppliers \& related industries and Enterprise structure, strategy, and rivalry average score are 6.5746 and 6.5715 respectively, which is not bad and touching towards good. It means garments industry is shifting to better with having above average national strength across the nation-state. There are many spinning mills operating in Pakistan, which are providing best and premium quality yarns and best services along with reasonable prices. Beyond the spinning industry, many other industries like accessories, packaging, etc., also providing good support the garment industry of Pakistan. In Pakistan, the textile is a major sector of the economy so the garments industry structure is strong and there are many small, medium and large scale organizations are operating in the country. There are many associations which are protecting the garments industry. Both autocratic and bureaucratic approaches are applied at management level. Due to tough competition, manufacturers are producing good quality garments with competitive prices which attract the foreign customers to work with Pakistani suppliers on along term basis.

Local Markets average score is 4.6043 , which is at a very limited level means Pakistani garment industry owing to some extent below the national average strength and shifting to mean level, it refers moving to national average length across the nationwide. Pakistani garments industry, mostly exports oriented 
and they don't pay attention to local markets and don't have good exposures in the local markets. Just because of that reason local markets have allow score because garments industry has no focused on local markets. The garments industry should pay attention to new product developments, new and innovated garments would attract to the domestic buyers and they will demand more such type of garments and this would be helpful to develop long term business relationships with customers. With more than 190 million populations, Pakistan has a big domestic market which can be entertained with best quality garments and competitive prices.

The external markets average score is 6.4061 , which is not bad and moving towards good. It means Pakistani garment industry exports are shifting to better with having a competitive edge across the country. GSP plus also facilitates the garment industry to grow the exports internationally. But very important, the government should assist the garment industry to develop and explore new markets across the world.
As per following table 3, product quality achieved the highest score, 8.0957 amongst all the sub-factors because the quality is very important at all levels for all the customers either nationally or internationally. Due to good cotton dye ability, Pakistani garments have the best quality around the world and even customers don't hesitate to pay more prices. If the quality of the garment is not good, customers will not bother to buy the garments even at cheap prices. On the opposite side, the local markets distinctiveness has very low score 4.1826 amongst all the sub-factors which means the Pakistani garment industry is mostly export oriented and they don't pay attention to local markets and don't have good exposures in the local markets. Standard Deviation describes that how much all the sub-factors deviate from an average score of the factors. The Pakistani garments unit should focus on the local markets with product differentiation.

The average score factors of all determinants of garments industry are 6.1976. All the three factors i.e. Groundings, Enterprises, and Markets have almost

Table 3

\begin{tabular}{|c|c|c|c|c|c|}
\hline No. & Sub-factor & $\begin{array}{c}\text { Avg. score } \\
(1-10)\end{array}$ & $\begin{array}{l}\text { Standard } \\
\text { deviation }\end{array}$ & $\begin{array}{l}\text { Avg. importance } \\
\text { score (1-7) }\end{array}$ & $\begin{array}{l}\text { Standard } \\
\text { deviation }\end{array}$ \\
\hline D4-6 & Product Quality & 8.0957 & 1.2065 & 6.7619 & 0.5390 \\
\hline D3-1 & Raw material availability & 7.6522 & 1.2499 & 6.5238 & 0.6796 \\
\hline D6-4 & Foreign market relationship & 7.3826 & 1.2536 & 6.0476 & 0.9735 \\
\hline D2-2 & Communication infrastructure & 7.3391 & 1.5269 & 6.4286 & 0.5976 \\
\hline D1-3 & Geographic Location & 7.2435 & 1.1207 & 5.9048 & 0.7003 \\
\hline D2-6 & Perfection of associated laws / rules & 7.2000 & 1.6233 & 6.2381 & 0.8309 \\
\hline D4-4 & The worth of brand name & 7.1652 & 1.3040 & 5.8571 & 1.2364 \\
\hline D1-1 & Labour force resources availability & 7.1043 & 1.3467 & 6.2381 & 0.8309 \\
\hline D2-1 & Transportation infrastructure & 7.1043 & 1.0952 & 6.2381 & 0.6249 \\
\hline D4-5 & Production Equipment & 7.0174 & 1.3827 & 6.3333 & 0.5774 \\
\hline D2-5 & Business Environment & 6.3913 & 1.4061 & 5.8095 & 0.9808 \\
\hline D3-2 & Services of suppliers & 6.3913 & 1.5142 & 6.1905 & 0.8729 \\
\hline D6-1 & Features of foreign end user & 6.3739 & 1.3538 & 5.6667 & 1.1547 \\
\hline D2-3 & Markets infrastructure & 6.3304 & 1.3619 & 5.1429 & 0.6547 \\
\hline D2-7 & Local Financial Market & 6.1826 & 1.1890 & 5.4286 & 0.9783 \\
\hline D6-3 & International market share & 6.1826 & 1.5309 & 5.6190 & 1.0713 \\
\hline D4-3 & The level of value added & 6.1652 & 1.5835 & 6.2857 & 0.7171 \\
\hline D1-2 & Talent Resources Availability & 6.0261 & 1.6515 & 5.9524 & 0.8646 \\
\hline D4-1 & Managerial skills & 5.8435 & 1.7701 & 5.9048 & 1.0911 \\
\hline D6-2 & Export \& trade barriers & 5.6435 & 1.7780 & 5.8571 & 0.9103 \\
\hline D3-3 & Development of related industries & 5.5304 & 1.9025 & 5.6667 & 0.8563 \\
\hline D2-4 & Trade Association & 5.4000 & 1.5435 & 4.7619 & 1.1792 \\
\hline D5-3 & Local market potential & 5.3217 & 1.6730 & 5.4286 & 1.2479 \\
\hline D2-8 & R\&D Institution & 5.2783 & 1.9082 & 6.0952 & 1.0911 \\
\hline D4-2 & The clarity of property right & 4.6435 & 1.7681 & 5.0952 & 0.9437 \\
\hline D2-9 & Vocational Training & 4.4870 & 2.1739 & 5.7143 & 1.1464 \\
\hline D5-2 & Local market share & 4.2696 & 1.8840 & 4.9524 & 1.1170 \\
\hline D5-1 & Local market distinctiveness & 4.1826 & 1.8945 & 5.2857 & 0.8452 \\
\hline
\end{tabular}


comparable score except local markets because Pakistan garment industry is export orient industry. But keeping in view the research results Pakistani garments industry should be focused on the local markets to increase the local market share as well. In this situation, competitive advantages would be supportive to become feasible in local and international markets. There should also be more stressed on the groundings and enterprises to optimum utilization of existing resources.

In sum, Pakistani garments industry has good strengths in raw material availability, product quality, communication infrastructure, foreign customer relationships and geographic location etc., whereas poor in local market share, local market distinctiveness, the clarity of property rights, vocational training and R\&D associations etc. To gain the good market share, Pakistani garments industry should be more focused on the weak areas to improve the garments competitiveness in the local markets as well as in the global markets.

\section{CONCLUSION}

The garment industry is varied and much diversified. Everyone is using the garments for his/her own use. Pakistani garments industry has the capability to offer an extensive range of garments with massive volume for exports to different world markets. In the recent era, the term competitiveness has become a very hot issue in the world. Like Japan is much competition in the electronics products, and at the present Japan's economy is leading in the world Due to increasingly tough competition of garment industry in the international markets, all Pakistani companies should have to find out the dynamics of competitive advantages and utilize them effectively to get the best business volumes in the global markets.

Many consultants/researchers have worked on competitiveness at all levels, such as at the industry level, at the national level and more precise at the firm level. The GEM model has been extensively applied in national as well as in international cluster analysis and also used to benchmark the particular industry. After thorough analysis, this model has evaluated and defined the strengths and weaknesses of garment industry of Pakistan. This research determined that so far the Pakistani garment industry is performing well in all the concerned areas; however, there are some key problems which can be removed to develop the garment industry at local markets and in global markets. Pakistan has enormous labour force resources availability; on the other hand, there are some unskilled and semi-skilled labours. But still the labour cost is inexpensive than other countries, so these factors can be supportive to become competitive in the foreign markets. There are good communication and transportation infrastructure to facilitate the garment industry of Pakistan. For communication, modern and up-to-date technology is available to contact the customers in different regions of the world and cheap communication reduces the produc- tion cost. Garments industry companies are normally privately owned by the domestic businessmen in Pakistan. They are keen to develop and explore the garments business by using various strategies according to the competition situations in domestic and global markets. There is good potential to materialize the local demand in Pakistan because generally local companies are full focusing on garment exports in different world markets and dealing with various brands to manufacture the garments according to their requirements. Now a day the consumer buys products or services not only to have them, but also to define his personality, his image and even his position in society. All these extra-values of a product are given nowadays by the brand [19]. The garment business, companies must work to launch their own brands in domestic and international markets and expand their business accordingly. This would supportive of new innovation in present garments products and the new garments as well as manage the buyer's demand accordingly. Pakistan is a $6^{\text {th }}$ largest populous country in the world with around more than 193 Million populations, this is a huge market for the local garment producers to capture and materialize the business in domestic markets.

The analyses are shown that GEM Score is 382 for the garment industry of Pakistan based on the primary data collection. Based on the GEM Score 382, if the score is between 250 and 640, it means that ready-made garment industry of Pakistan is above the national average level and owns competitive advantages nationwide. The average score factors of all determinants of garment industry are 6.1976. All the three factors, i.e. Groundings, Enterprises, and Markets have an almost comparable score except local markets because the Pakistani garment industry is an export orient industry. But keeping in view, the research results Pakistani garment industry should be focused on the local markets to increase the local market share as well. In this situation, competitive advantages would be supportive to become feasible in local and international markets. There should also be more stressed on the groundings and enterprises to optimum utilization of existing resources.

In order to evaluate the overall scores of all the subfactors, product quality achieved the highest score, 8.0957 amongst all the sub-factors because the quality is very important at all levels for all the customers either nationally or internationally. Due to good cotton dye ability, Pakistani garments have the best quality around the world and even customers don't hesitate to pay even more prices just because of quality level. On the opposite side, the local markets distinctiveness has very low score 4.1826 amongst all the subfactors which means the Pakistani garment industry is mostly export oriented and they don't pay attention to local markets and don't have good exposures in the local markets. The Pakistani garments unit should focus on the local markets with product differentiation as Pakistan has also a big market with more than 193 Million populations. 


\section{Future research scope}

GEM Model has assessed the competitiveness of Pakistani garments industry in the global markets. This model is worth for further evaluation. This research paper has focused on almost all factors which are affecting the competitiveness of garment industry of Pakistan. So another interesting area of research could be studied like the relationships between one or numerous factors and the competitiveness of garment industry of Pakistan. For instance, the wages cost and the competitiveness, the clusters relationship and the competitiveness. Moreover, existing GEM model of competitiveness can also be applied in other textiles sectors like spinning, weaving etc. to check the possibility of findings other determinants which are impacting the competitiveness of an industry on the cluster level. GEM model has been extensively applied to nationals and international clusters examination to benchmark the industry. After thorough analysis, the GEM model can evaluate and define the strengths and weaknesses of garment industry of Pakistan.

\section{Practical implications}

This research study has significant practical implications for several regional governments, garment enterprises, garment associations, R\&D institutions for assessing the garments industry competitiveness. Through applying this model, the firm can identify their strengths and weaknesses to confront the competition level and helpful to make best decisions accordingly. This research work also provides guidance to the industry managers, consultants, researchers and experts that where the garment industry stands up at the instant, after detailed analysis, they could take useful decisions to increase the competitiveness level of garments industry.

\section{BIBLIOGRAPHY}

[1] Ahmad, N., \& Kalim, R. (2014). Implications of export competitiveness, and performance of Textile and Clothing Sector of Pakistan: Pre and post quota analysis. In: Pakistan Journal of Commerce and Social Sciences, 8(3), pp. 696-714.

[2] Bevilacqua, M., \& Braglia, M. (2000). The analytic hierarchy process applied to maintenance strategy selection. In: Reliability Engineering \& System Safety, 70(1), pp. 71-83.

[3] Caisheng, M. (2012). Research on dynamic model of a single industry innovation cluster in the local universities' Sci-tech Parks [J]. In: Research in Higher Education of Engineering, 3, 018.

[4] Cheng, E. W., \& Li, H. (2001). Analytic hierarchy process: an approach to determine measures for business performance. In: Measuring business excellence, 5(3), pp. 30-37.

[5] Delgado, M., Ketels, C., Porter, M. E., \& Stern, S. (2012). The determinants of national competitiveness. In: NBER Working Paper No 18249 Cambridge, MA: National Bureau of Economic Research.

[6] Economic survey of Pakistan 2014-2015. In: Accessed and Retrieved on December 06, 2016 http://www.finance.gov.pk/survey/chapters_15/03_Manufacturing.pdf

[7] Erbas, E., \& Perçin, N.S. (2015). Competitive Importance Performance Analysis (CIPA): An illustration from thermal tourism destinations. In: Business and Economics Research Journal, 6(4), p. 137.

[8] Ghosh, B., Kumuthadevi, K., \& Jublee, D. (2016). Linkage among competitiveness, competitive advantage and competitive priority of apparel export firms at tirupur. In: International Journal of Management Research and Reviews, 6(8), p. 1012.

[9] Irshad, M.S., \& Xin, Q. (2017). Determinants of exports competitiveness: An empirical analysis through revealed comparative advantage of external sector of Pakistan. In: Asian Economic and Financial Review, 6(3), pp. 623-633.

[10] Irshad, M.S., Xin, Q., Xuan, L., \& Arsahd, H. (2016). Deltoid analysis of Pakistan-ASEAN-China Free Trade Agreements and Opportunities for Pakistan.

[11] Khan, S., \& Shah, S.M.A. (2017). Study on key empirical factors of competitiveness: Case of Textile Industry of Pakistan. In: Journal of Managerial Sciences, 11(1).

[12] Khan, S., Murtaza, G., Jamil, R.A., \& Qadir, I. (2017). Confirmatory analysis of the factors of competitiveness in the Textile Industry of Pakistan. In: Sarhad Journal of Management Sciences, 3(01), pp. 70-83.

[13] Lee, C.F., \& King, B. (2010). International competitiveness in hot springs tourism: An application of the analytical hierarchy process approach. In: Tourism Analysis, 15(5), pp. 531-544.

[14] Mayer J. (2003). Trade integration and shifting comparative advantage in labor-intensive manufactures. Paper presented at the UNU/WIDER Conference on Sharing Global Prosperity, Helsinki, 6-7 September.

[15] Olamade, O. (2015). Nigeria in global competitiveness comparison. In: Journal of Economics, 3(2), pp. $146-158$.

[16] Padmore, T., \& Gibson, H. (1998). Modelling systems of innovation: Il. A framework for industrial cluster analysis in regions. In: Research policy, 26(6), pp. 625-641.

[17] Pakistan's falling cotton production (2017). In: Accessed and Retrieved on December 01,2017 https://tribune.com.pk/story/1296035/curious-case-pakistans-falling-cotton-production/

[18] Peng. M.W, (2014), Global Strategic Management, In: $3^{\text {rd }}$ International Edition, CENGAGE Learning, 2014. 
[19] Popa, A., \& Pelau, C. (2016). Differences in the clothing brand perception depending on generation / Diferențe în percepția brandurilor de îmbrăcăminte în funcție de generație. In: Industria Textila, 67(4), p. 260.

[20] Porter, M.E. (1990). The competitive advantage of notions. In: Harvard Business Review, 68(2), pp. $73-93$.

[21] Qadir, U. (2016). Technology acquisition, catching up and competitiveness in Pakistan (No. 2016: 134). Pakistan Institute of Development Economics.

[22] Saaty, T.L. (1980). The analytic hierarchy process, New York: McGrew Hill. International, translated to Russian, Portuguesses and Chinese, Revised edition, Paperback (1996, 2000), Pittsburgh: RWS Publications.

[23] Saaty, T.L. (2008). Decision making with the analytic hierarchy process. In: International journal of services sciences, 1(1), pp. 83-98.

[24] Sharp, M., Holmes, P., (1989). Strategies for new technology: Case studies from Britain and France. Philip Allan, New York.

[25 Statistics on textile industry in Pakistan, (2013). In: Accessed and retrieved on December 02,2016 http://tribune.com.pk/story/522292/statistics-on-textile-industry-in-pakistan

[26] Vaidya, O.S., \& Kumar, S. (2006). Analytic hierarchy process: An overview of applications. In: European Journal of operational research, 169(1), pp. 1-29.

[27] Wang, C.R. (2005). Analysis of the competitiveness of the Ningbo garment industry.

[28] Yang, Q. (2017). Study on The Industrial Cluster of Tropical Bananas Based on Gem Model. In: Acta Universitatis Cibiniensis. Series E: Food Technology, 21(1), pp. 69-74.

[29] Zahedi, F. (1986). The analytic hierarchy process-a survey of the method and its applications. In: Interfaces, 16(4), pp. 96-108.

[30] Zhao, C., Liu, X., \& Zhang, Z. (2016). The compared study of competitiveness of Electron Industry Clusters: Case of Wuhan, Shanghai and Guangzhou. DEStech. In: Transactions on Computer Science and Engineering, (icte).

[31] Zia, U. (2007). International competitiveness - Where Pakistan stands? In: (No. 2007: 28). Pakistan Institute of Development Economics.

\section{Authors: \\ ASIF ALI SAFEER ${ }^{1}$, MUHAMMAD ABRAR ${ }^{2}$ \\ SAJJAD AHMAD BAIG, ${ }^{1}$ \\ ABDUL BASIT ${ }^{3}$, \\ MUHAMMAD ZIA-UR-REHAMAN ${ }^{1}$ \\ MUHAMMAD HASHIM ${ }^{1}$}

\footnotetext{
${ }^{1}$ Department of Management Sciences, National Textile University Faisalabad, Pakistan

${ }^{2}$ Associate Professor, Lyallpur Business School (LBS), GC University, Faisalabad, Pakistan

${ }^{3}$ Department of Yarn Manufacturing, National Textile University Faisalabad, Pakistan
}

Corresponding author:

SAJJAD AHMAD BAIG

e-mail: sajjad.baig@hotmail.com

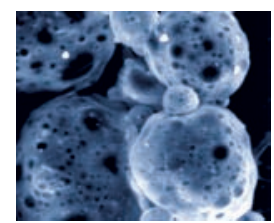

